
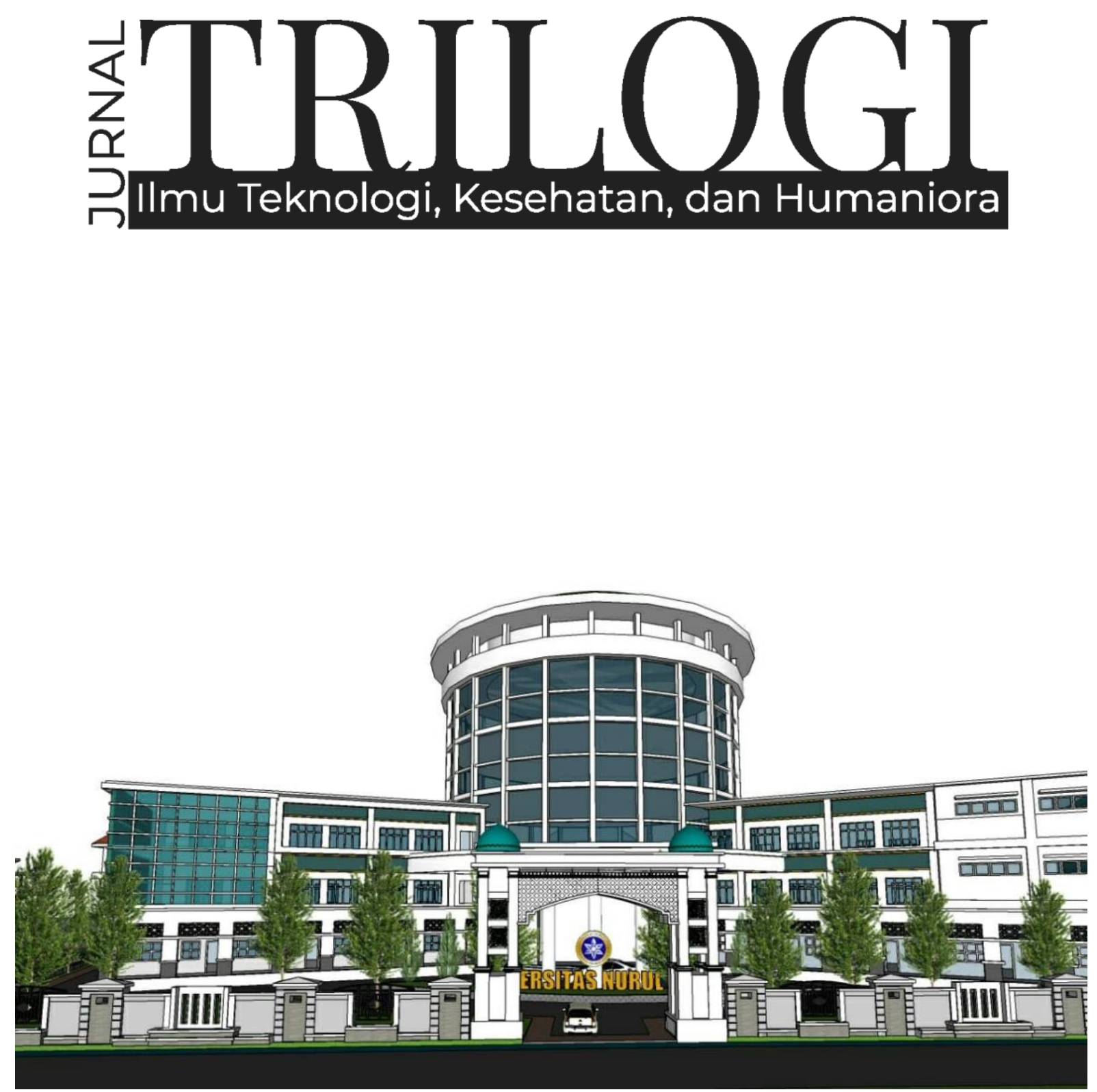

PENGEMBANGAN PENDIDIKAN DAN EKONOMI PESANTREN DI MASA PANDEMI COVID-19 


\section{犃BUOGI}

Vol. 2, No. 2, 2021

Editor in Chief

Achmad Fawaid, (SCOPUS ID: 57214837323)

\section{Managing Editors}

Hasan Baharun, (ID SCOPUS : 57200983602)

Sugiono Sugiono, (SCOPUS ID : 57199578160)

Ismail Marzuki, (SCOPUS ID: 57201500245

Subhan Rachman, (SCOPUS ID: 57192937912)

Nurul Huda, (SINTA ID: 6119615)

Syamsuri, (SINTA ID: 6116825)

Ridhatullah Assya'bani, (SINTA ID: 6200862)

\section{Peer Reviewers}

Miftahul Huda, (SINTA ID: 6171566), University of Antwerp, Belgium

Achmad Naufal Irsyadi, (SINTA ID: 6704870), Universitas Nurul Jadid, Indonesia

Gulpi Qorik Oktagalu P., (SINTA ID: 5982074) Universitas Nurul Jadid Probolinggo, Indonesia Hozairi, (SINTA ID: 166198), Universitas Islam Madura, Indonesia

Nur Hamid, (SINTA ID : 6744813), Univeristas Nurul Jadid Probolinggo, Indonesia Zainal Munir, (SINTA ID: 6672512), Universitas Nurul Jadid Probolinggo, Indonesia Sri Astutik Andayani, (SINTA ID: 6172559), Universitas Nurul Jadid Probolinggo, Indonesia Sukamto Sukamto, (SINTA ID: 5979034), Universitas Widya Gama Malang, Indonesia Deny Utomo, (SINTA ID: 6016108), Universitas Yudharta Pasuruan, Indonesia Fariz Alnizar, (SCOPUS ID: 6659824), UNUSIA Jakarta, Indonesia

Fuad Rahman, (SCOPUS ID: 57201474778), UIN Sulthan Thaha Saifuddin Jambi, Indonesia Saifuddin Zuhri Qudsy, (SCOPUS ID: 57213595165), UIN Sunan Kalijaga Yogyakarta, Indonesia Akhmad Anwar Dani, (SINTA ID: 14305), IAIN Surakarta, Indonesia

Maufur Maufur, (SINTA ID: 5989329), IAIN Kediri, Indonesia

Siti Mahmudah Noorhayati, (SINTA ID: 6726997), IAIN La Roiba Bogor, Indonesia Busro Busro, (SCOPUS ID: 57205022652), UIN Sunan Gunung Djati Bandung, Indonesia Akmal Mundiri, (SCOPUS ID: 57205059378), UNUJA Probolinggo, Indonesia

\section{Section Editor}

Ahmad Zubaidi, Universitas Nurul Jadid, Probolinggo, Indonesia 
TRILOGI: Jurnal IImu Teknologi, Kesehatan, dan Humaniora is a peer-reviewed journal, open-access journal which publishes original articles on various issues within technology, health, and social humanities, which include but are not limited to newrenewable energy, food-agriculture, health-pharmacy, transportation, informationcommunication technology, advanced-materials, maritime-infrastructre, social-artseducation, and religious studies based on academic and scientific research.

TRILOGI: Jurnal IImu Teknologi, Kesehatan, dan Humaniora seeks to publish a balanced mix of theoretical or empirical articles, case studies, review papers, comparative studies, exploratory papers, and book reviews. All accepted manuscripts will be possibly published both online and in printed forms.

Editorial Office:

TRILOGI: Jurnal IImu Teknologi, Kesehatan, dan Humaniora Lembaga Penerbitan, Penelitian, dan Pengabdian kepada Masyarakat (LP3M) Universitas Nurul Jadid, Paiton, Probolinggo, Jawa Timur, Indonesia 67291.

Phone: 088830 77077, Hp: 082318007953

Email: jurnal.trilogi@gmail.com

Website: https://ejournal.unuja.ac.id/index.php/trilogi/index 


\section{Tables of Content}

71-76

Pengaruh Metode Pembelajaran Daring dengan Aplikasi Google Classroom terhadap Hasil Belajar Siswa Madrasah Ibtidaiyah Nurul Mun'im Paiton Probolinggo

Feriska Listrianti, Lailatul Munawwaroh, Sayyidatul Arifa, Siti Aisyah

77-84

Inklusivitas dan Responsivitas Pesantren dalam Penanganan Pandemi Covid 19: Telaah Hidden Curriculum Pembelajaran di Pondok Pesantren Nurul Jadid

Zakiyah BZ, Uswatun Hasnah, Nafistur Rahmah

84-94

Integrasi Kurikulum Madrasah Diniyah dengan Lembaga Formal dalam Meningkatkan Mutu Lulusan di Sekolah Menengah Pertama (SMP) Nurul Jadid Paiton Probolinggo

Abdurrahman, Ika Fitri Anwar, Sofiya Mauliza, Nadya Afkarina

95-104

Some Issues on Time Deposit Financing: An Islamic Perspective on Mudharabah Agreement at Baitul Maal wa Tamwil (BMT) NU in Randuagung Lumajang

Saifuddin, Abdul Hafid, Hengki Wahyu Pratama

$105-110$

Analisis Pengembangan Potensi Ekonomi Keluarga melalui Unit Usaha Kapuk

Fahrudin, Iis Sa'diyah, Rizaldi Chandra Gunawan

111-117

Penguatan Ekonomi Pesantren melalui Pengembangan Ekonomi Masyarakat Pesisir: Pelajaran dari Pondok Pesantren Nurul Jadid Paiton Probolinggo

Achmad Febrianto, Muhammad Habibullah, Aksal Ilhamsyah

118-125

Prevensi Perilaku Konsumtif Persepektif Abraham Maslow dan Tri Logi Santri

Muhammad Syaiful Suib, Habibatur Rizkiyah, Fitria Nur Ain 
$126-136$

Manajemen Pengembangan Kurikulum Berorientasi pada Pembentukan Karakter

Moh Rifa'i, Fatimah Al Zahra, Abdurrahman Abdurrahman, Mukhlisin Saad

137-147

Home Industry, Kaderisasi, dan Santripreneur

Muh Hamzah, Aprilinda Dwi Kurniawati, Husnul Khotimah

148-157

Rancangan Pengelolaan Nirsampah Mandiri Skala Lembaga Pendidikan

Tirmidi, Eril Sinta Nuriyah, Rofi'ah

158-166

Parents' Knowledge and Commitment To Stimulate Child Development

Lailatul Fitriyah, Nurul Islamiyah, Auliya' Fatahillah

167-172

Implementasi Pembelajaran Akhlak Berbasis Multikultural pada Masa Pandemi di Madrasah Tsanawiyah Nurul Jadid Paiton Probolinggo

Abdullah, Yusrolana, Nur Laily

$173-183$

Implementasi Evaluasi Pembelajaran Daring (Online) melalui Home Visit

Moch Tohet, Moh. Bagus Abdillah, Adam Hakim Al Rizki

184-192

Efektivitas Pembelajaran Luring pada Mata Pelajaran Matematika selama Pandemi Covid-19

Zaenol Fajri, Sukron Junaidi, Hamdani Alfarisi 
P-ISSN: 2774-4574; E-ISSN: 2774-4582

TRILOGI, 2(2), Mei-Agustus 2021 (71-76) @ 2021 Lembaga Penerbitan, Penelitian, dan Pengabdian kepada Masyarakat (LP3M) Universitas Nurul Jadid Paiton Probolinggo

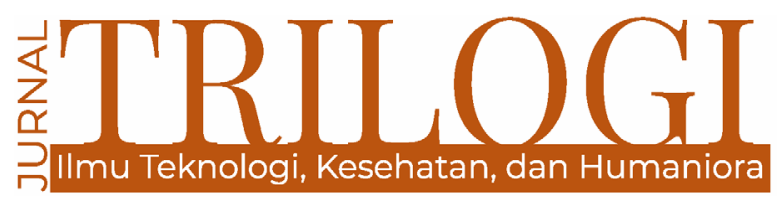

\title{
PENGARUH METODE PEMBELAJARAN DARING DENGAN APLIKASI GOOGLE CLASSROOM TERHADAP HASIL BELAJAR SISWA MADRASAH IBTIDAIYAH NURUL MUN'IM PAITON PROBOLINGGO
}

\section{Feriska Listrianti}

Universitas Nurul Jadid, Probolinggo

feriskal@unuja.ac.id

\section{Lailatul Munawwaroh}

Universitas Nurul Jadid, Probolinggo

lailatulmunawwaroh96@gmail.com

\section{Sayyidatul Arifa}

Universitas Nurul Jadid, Probolinggo

sayyidatul.arifa@gmail.com

\section{Siti Aisyah}

Universitas Nurul Jadid, Probolinggo

aisyah.pgmi@gmail.com

\begin{abstract}
Online learning is an alternative learning in during a pandemic Covid-19 in elementary school children for IPS subjects. This situation makes some students feel saturated because the method of learning, through lecturer and assigment, is monotonous. Teachers are required to be able to control various kinds of learning platforms that have been provided with the capacity to increase student motivation. This study aims to connect online learning using Google Classroom media in social studies subjects for th $6^{\text {th }}$ grade students of VI Nurul Mun'im. The research method is pre experimental dataset analysis techniques using intact design comperision group. Data was taken in the $6^{\text {th }}$ grade of 28 students divided into 2 classes (VI B and VI C), each numbered 14 students as a class of control and experimental groups, with the mean value (average value) for group experiments with mean (average value - evenly) 89.63 and for the 80.78 control group, difference 8.85. The analysis of Mann Whitney produced a value of the P-Value $0.00<0.05$ which showed the influence of the online learning model on the results of the social science learning process (IPS). His publication, there is a significant difference between the online learning process of Google Classroom with conventional learning techniques. The results of this study provide benefits and feedback for teachers in implementing online learning model to improve student achievement results, especially in Social Science (IPS).
\end{abstract}

Keywords: Online Learning; Social Lessons; Learning Outcomes 


\begin{abstract}
Abstrak
Dasar untuk mata pelajaran IPS. Situasi ini membuat sebagian siswa merasa jenuh dikarenakan metode pembelajarannya monoton melalui metode ceramah dan beban tugas. Guru dituntut untuk dapat menguasai berbagai macam platformpembelajaran yang telah disediakan dengan kapasitas untuk meningkatkan motivasi belajar dari siswa. Penelitian ini bertujuan mengkoneksikan pembelajaran daring menggunakan media Google Classroom pada mata pelajaran IPS bagi siswa kelas VI MI Nurul Mun'im. Metode yang digunakan adalah teknik analisis dataset pre eksperimen dengan menggunakan desain intact grup comperision. Data diambil pada kelas VI berjumlah 28 peserta didik dibagi 2 kelas yaitu kelas VI B dan VI C masing-masing berjumlah 14 peserta didik sebagai kelas kelompok kontrol dan eksperimen, dengan nilai Mean (nilai rata - rata) untuk klompok eksperimen dengan Mean (nilai rata - rata) 89.63 serta untuk kelompok kontrol 80.78, difference 8.85. Analisis dari Mann Whitney menghasilkan nilai dari $p$-valuue $0,00<0,05$ yang menunjukkan terdapat pengaruh model pembelajaran daring pada hasil dari proses belajar Ilmu Pengetahuan Sosial (IPS). Kasimpulannya, ada perbedaan signifikan antara proses pembelajaran daring Google classroom dengan teknik pembelajara secara konvensional. Hasil penelitian ini memberikan manfaat serta masukan bagi guru MI Nurul Mun'in untuk mengimplemintasikan model pembelajaran daring untuk meningkatkan hasil prestasi belajar siswa dimana kususnya mata pelajaran Ilmu Pengetahuan Sosial (IPS).
\end{abstract}

Katakunci: Pembelajaran Daring; Pelajaran IPS; Hasil Belajar

\section{Pendahuluan}

Pertumbuhan teknologi komunikasi di era globalisasi memberi dampak yang dirasakan oleh masyarakat begitu signifikan dalam berbagai aspek kehidupan. Yang mana masyarakat dengan mudahnya mendapatkan informasi pengetahuan dan pemahaman dari media internet yang merupakan salah satu aspek pembelajaran. Dengan banyak sumber-sumber yang tersebar luas di dunia internet mempermudah masyrakat bisa mengakses internet dengan menggunakan gadget maupun smartphones (Eko, 2017).

Indonesia dihadapkan pada tantangan masa revolusi industri 4.0. Tidak cuma zona ekonomi, sosial, serta teknologi, tetapi zona pendidikan saat ini juga harus dapat menyesuaikan diri dengan media informasi dan teknologi masa kini. Pertumbuhan itu sudah mulai bisa dimanfaatkan oleh sebagian sekolah dasar atau madrasah ibtidaiyah di negara Indonesia pada penyelenggara program pendidikan. Program tersebut diketahui selaku program pembelajaran secara daring ataupun sistem e-learning ataupun online learning - Belajar daring ialah memanfaatkan jaringan internet dalam proses pendidikan (Albitar , 2020).

Dalam pembelajaran daring itu sendiri bisa dipahami bahwa pendidikan formal di selenggarakan oleh madrasah ibtida'iyah atau sekolah dasar yang mana siswa atau peserta didik dan guru ada dilokasi yang berbeda atau terpisah sehingga perlu suatu sistem telekomunikasi secara interaktif antara guru dan peserta didik untuk menyambungkan antara keduanya serta sumber informasi yang di perlukan di dalamnya. Pembelajaran ialah interaksi guru dan siswa dalam memberikan pengetahun dan informasi secara langsung (Sobron A.N, Bayu, Rani, \& Meidawati, 2019).

Keunggulan pembelajaran dengan sistem daring seluruh masyarakat di indonesia bisa mengikuti program pembelajaran daring. Misal, anak yang bersekolah di madrasah ibtida'iyah ingin mendapatkan ilmu dan pendidikan yang sama disekolah unggulan yang letaknya berada diluar daerah. Dimana kondisi dan situasi tidak memungkinkan karena tidak bisa meninggalkan rumah. Maka dengan adanya pembelajaran daring anak didik madrasah ibtida'iyah tersebut bisa tetap mengikuti program pembelajaran tanpa harus datang langsung ke sekolah dan meninggalkan rumahnya. sehingga bisa menekan tenaga dan biaya, serta wantu yang terbuang. Pembelajaran daring memberi cara pembelajaran yang lebih efektif, dengan adanya feedback yang terkait, mengkolaborasikan antara kegiatan dengan cara belajar secara mandiri, personal pembelajaran berdasar kebutuhan anak didik dengan memanfattkan permainan dan simulasi (Roman, Paulus, \& Eko, 2019).

Dengan berkembangnya teknologi informasi sangat memungkinkan proses pembelajaran 
yang seharusnya di dalam kelas bisa di akses dimanapun saja maupun di rumah. Komunikasi dengan dua arah pada proses pembelajaran daring siswa denagn siswa atau siswa dengan guru, serta antara guru yang satu dengan guru yang laiinya akan lebih baik karena banyak tersedianya media komunikasi yang ada. Media komunikasi yang begitu banyak pilihan sangat memungkinkan para pendidik atau guru dalam proser belajar-mengajar secara langsung melalui vidio conferance atau menggunakan audio yang di rekam. serta pada proses yang selanjtnya siswa bisa mendownload atau di putar langsung secara berulang kali bila ada materi yang susah dipahami (Aniq \& Siti , 2020).

Peserta didik yang menggunakan proses pembelajaran daring bisa lebih menghemat tenaga, wantu serta biaya yang dikeluarkan. Dimana tenaga dan waktu bisa digunakan untuk kegiatan lainnya di luar jam belajar. Misal, dapat di gunakan untuk upgrade pengetahuan sesuai dengan perkembangan jaman. Hal tersebut bisa di lakukan pembelajaran tidak hanya materi saja. Masa pembelajaran bisa di gunakan selain di bidang akademik seperti menggalai potensipotensi dan keterampilan. Dalam mempersiapkan proses pembelajaran daring, madrasah ibtida'iyah harus ada persiapan yang matang sesuai kebutuhan seperti infrastuktur, sumberdaya manusia dan sarana prasarana penunjang lainnya. Memang dalam menghadapi era digitalisasi harus di lakukan secepatnya karena perkembangan teknologi sangat begitu cepat serta tidak dapat di bendung (Hikmat, Endang , Aldim, \& Irwandi, 2020).

Sarana prasarana yang harus disiapkan madrasah ibtida'iyah di antaranya, seperti sarana prasarana platform seperti jaringan internet, wifie, komputer dan proyektor yang digunakan dalam proses pembelajaran secara daring, dan yang terpenting ialah satu fasilitas profil data sekolah serta informasis yang disampaikan dengan baik dikalangan pendidik itu sendiri maupun yang di didik. Pendidikan diera revolusi industri 4.0 dimana masih banyak terdapat banyak maslah dalam transfer informasi yang terhalang dikarenakan masalah pada sistem yang belum bisa di miliki oleh institusi pendidikan sangat kurang baik, langkah-langkah yang bisa di pilih dengan cara pemanfaatan teknologi informasi dalam pembelajaran menggunakan pemebelajaran daring dilingkungan sekolah maupun masyarakat. Kedua sumber daya manusia yang mampu dalam memanfaatkan teknologi informasi dalam proses pembelajaran daring, tentunya sekolah harus menyiapkan sumber daya manusia yang paham tentang masalah sistem yang akan diimplementasikan, seperti platform yang akan dipakai dalam proses pembelajaran model daring, serta menyiapkan penanggung jawab dalam penyediann bahan ajar dan materi yang akan digunakan dalam proses pembelajaran model daring, serta menyiapkan kebutuhan-kebutuhan yang lainnya. Ketiga yaitu akreditasi, dimana akreditasi menjadi faktor penunjang yang harus dipersiapkan, terkait kualitas institusi sekolah bisa dipercaya oleh calon peserta didik dan orang tua siswa dengan akreditasi yang baik, seandainya sekolah dengan akreditasi $\mathrm{C}$ tentunya yang akan mendaftar pada program daring akan ragu untuk mendaftar di sekolah tersebut.

Pada Proses pembelajaran daring mempunyai banyak manfaat, yang pertama bisa membangun sebuah diskusi dan komunikasi dengan efisien antar siswa dan guru, yang kedua siswa yang satu dengan siswa yang lainnya dapat berinteraksi dan berdiskusi tanpa harus melalui perantara guru, yang ketiga mempermudah siswa, guru, dan orang tua wali dalam berinteraksi, yang keempat memepermudah guru dalam memeberikan ujian atau kuis, yang kelima mempermudah guru dalam memeberikan materi baik dalam bentuk vidio, gambar maupun audio, selain itu siswa bisa juga mendownload materi yang ada, yang keenam memudahkan guru dalam pembuatan dan pendistribusian soal ujian kapan saja dan dimana saja.

Pembelajaran Ilmu Pengetahuan Sosial (IPS) berbasis Daring yang di lakukan di kelas VI Mi Nurul Mun'im dengan menggunakan aplikasi Google Classroom. Aplikasi Google Classroom adalah sebuah aplikasi yang dibuat untuk guru, siswa serta wali siswa untuk mempermudah dalam berkomunikasi tanpa harus memperhatikan tempat dan waktu. Manfaat Google Classroom yang lainnya untuk mendistribusikan soal ujian, tugas sekolah, dan pekerjaan rumah. Tiap guru dan siswa pada kelas VI MI Nurul Mun'im Desa Karanganyar Paiton probolinggo menggunakan aplikasi platform Goggle Calssroom serta memiliki akun goole Classroom sebagai media belajar daring Ilmu Pengetahuan Sosial (Ni , 2020).

Proses pembelajaran yang ada di MI Nurul Mun'im yang terletak di Desa Karanganyar Paiton Probolinggo dimana pada proses pembelajaran secara daring berlangsung dengan tertib dan baik. Siswa merasa senang dalam proses pembelajaran secara daring karena siswa meskipun berada di rumah atau diluar sekolah tetap bisa menyimak 
materi yang disampaikan oleg gurunya dan materi IPS yang telah diberikan sebelumnya oleh guru bisa di akses ulang oleh siswa dan siswa tidak segan lagi dalam berdiskusi dengan guru tentang materi yang dibahas. Siswa cukup bertanya pada kolom komentar yang telah disediakan sehinggga siswa begitu antusian dan percaya diri untuk bertanya. Untuk materi Ilmu Pengetahuan Sosial (IPS) yang diberikan pada proses pembelajaran daring di Mi Nurul Mun'im desa Karanganyar paiton probolinggo bisa selesai tepat waktu sesuai jam mengajar meski guru dan siswa jarang bertemu dan masuk kelas di sekolah.

Dengan pembelajaran daring menggunakan Google Classroom tersebut maka pada penelitian ini peneliti mempunyai tujuan untuk mengetahui hubungan dalam pembelajaran daring tentang hasil yang berupa data untuk penambahan setelah proses hasil belajar siswa yang di lakukan di Mi Nurul Mun'im Desa Karanganyar Paiton Probolinggo.

Rumusan masalah dalam penelitian ini yaitu ada pengaruh Daring Learning terhadap hasil Belajar Ilmu Pengetahuan Sosial di Madrasah Ibtidaiyah Nurul Mun'im Karanganyar Paiton Probolinggo. Adapun manfaat dalam penulisan ini yaitu hasil penelitian ini dapat memberikan tambahan wawasan dalam menerapkan media Daring

Learning pada pembelajaran IImu Pengetahuan Sosial pada siswa kelas IV Madrasah Ibtidaiyah Nurul Mun'im Karanganyar Paiton Probolinggo. Selain itu, penelitian ini juga dapat dijadikan sebagai referensi penelitian selanjutnya yang berkaitan. Dengan Daring Learning edmodo tersebut maka penelitian ini bertujuan untuk mengetahui apakah ada pengaruh Daring Learning Terhadap Hasil Belajar IImu Pengetahuan Sosial di Madrasah Ibtidaiyah Nurul Mun'im Karanganyar Paiton Probolinggo.

\section{Metode}

Pada penelitian ini metode yang digunakan yaitu melalui riset kuantitatif dengan proses pre eksperimen dengan tipe intact tim comperison. Pada prosedur eksperimen adalah metode pengujian hipotesis yang bentuh hubungannya terkait sebab-akibat dengan memanipulasi variabel yang independen serta menguji perubahan yang di akibatkan oleh manipulasi tersebut. Alat yang digunakan dalam proses pengumpulan dataset dengan menggunakan Quisioner. Penelitian dilaksanakan pada bulan Maret - Juni 2021 di Madrasah Ibtidaiyah Nurul
Mun'im Karanganyar Paiton Probolinggo. Alat yang digunakan untuk pengumpulan data berupa quisioner, populasi dalam penelitian merupakan wilayah generalisasi yang terdiri dari subjek yang mempunyai karakteristik dan kualitas tertentu yang diimplementasi oleh peneliti untuk dipelajari dan kemudian bisa ditarik kesimpulan awal (Sobron, Titik, \& Meidawati, 2020). Jumlah populasi pada penelitian ini berjumlah 28 siswa Mi Nurul Mun'im Desa Karanganyar Paiton Probolinggo. Selanjutnya responden akan dibagi menjadi dua bagian kelompok yang mana kelompok pertama sebanyak 14 siswa menjadi keompok kelas eksperimen, dan yang kedua sebanyak 14 siswa di jadikan sebagai kelompok kelas kontrol. Quisioner yang dibuat oleh peneliti, siswa diberi kebebasan dalam memilih dan menjawab jawaban yang telah di sediakan oleh peneliti dalam form quisioner yang telah diberikan, quisioner yang dibuat dan diberikan pada post test berupa pilihan ganda (sesudah proses pembelajaran daring menggunakan google classroom). Quisioner pada pembelajaran daring google classromm dilakukan pengujian reliabilitas dan validitas di MI Al-ISLAMIYAH Karanganyar paiton sebanyak 20 siswa sebagai responden, dari hasil pertanyaan sebanyak 30 butir dan untuk pertanyaan yang dinyatakan reliable dan valid sebanyak 20 butir pertanyaan. Selanjutnya pada proses analisis data di tentukan setelah dilakukan pengujian normalisasi, hasil dari pengujian normalisasi data menggunakan shapiro wilk memperlihatkan hasil penelitian dengan nilai sig $<0,05$ yang mana penelitian dikatakan tidak berdistribusi normal, sehingga proses analisis data yaitu mann whitney yang mana analisis harus dilakukan menggunakan uji non parametrik.

\section{Hasil dan Pembahasan}

Pembelajaran IPS di Madrasah Ibtida'iyah (MI) merupakan pembelajaran pokok yang wajib dipelajari oleh siswa didik. Pembelajaran IPs di MI merupakan pembelajaran pokok yang harus di tempuh di jenjang MTs dan MA sederajat. IImu pengetahuan sosial adalah ilmu yang terhubung dengan banyak aspek, yang mana diantaranya interaksi manusia dengan keadaan, nilai, norma sosial, serta suatu perubahan yang begitu berpengaruh dalam kegiatan pembelajaran (Novi, Fatimatul, \& Farid , 2020).

Pembelajaran IPS berbasis daring memanfaatkan aplikasi Goggle Classroom. Goggle Classroom ialah teknik pembelajaran media 
sosial yang tidak dipungut biaya dan juga aman dan mempermudah guru dalam mengelola dan membuat kelas online sehingga siswa dan guru serta teman sekelas bisas terkoneksi dan berinteraksi dimana saja dan kapan saja. Goggle Classroom membantu para guru dalam mengelola dan membangun sebuah kelas online berdasar pembagian kelas nyata sesuai jadwal yang diberikan oleh sekolah, di mana di dalam kelas terdapat pemberian materi, quis, penugasan serta pemberian nilai langsung tiap akhir proses pembelajaran. Goggle Classroom itu sendiri di kembangkan oleh Googgle berupa platform media pembelajaran agar terhubung dan berkolaborasi antara guru dan siswa dalam proses pembelajaran (Frikson, 2020).

Table 1. Hasil Gambaran belajar IPS siswa setelah Daring

\begin{tabular}{lllllll}
\hline No & Variabel & N & Min & Max & Mean & $\begin{array}{c}\text { Standar } \\
\text { Deviasi }\end{array}$ \\
\hline 1 & $\begin{array}{l}\text { Kelompok } \\
\text { eksperimen }\end{array}$ & 14 & 80 & 95 & 89.63 & 5.19 \\
\hline 2 & $\begin{array}{l}\text { Kelompok } \\
\text { kontrol }\end{array}$ & 14 & 75 & 85 & 80.78 & 4.00 \\
\hline
\end{tabular}

Pada tabel 1 di atas diketahui bahwa hasil penelitian dari 14 responden bagi kelompok eksperimen mendapatkan nilai Minimum 80, Maximum 95, Mean (nilai rata - rata) 89.63 serta SD (Standar Deviasi) 5.19. Sedangkan hasip yang didapat olek kelompok kontrol mendapat nilai Minimum 75, Maximum 85, Mean 80.78 serta SD (Standar Deviasi) 4.00.

Hasil Pnelitian tersebut yang di dapat dengan menggunakan model pembelajaran daring dengan aplikasi Google Classroom sudah sesuai dengan teori. Pembelajaran daring menurut teorinya ialah model pembelajaran yang mewajibkan peserta didik untuk menemukan hubungan atau prinsip yang tidak diketahui sbelumnya yang merupakan dampak dari proses pengalaman belajar yang sudah diatur oleh guru secara seksaman dan cermat. Pembelajaran daring mempunyai arti bahwasanya peserta didik sebagai subjek pada proses pembelajaran. Kemampuan dasar yang dimiliki oleh siswa untuk proses perkembangan secara ideal sesuai dengan kemampuan yang sudah ada dan di miliki. Guru selaku pembimbing dan fasilitator bagi siswa untuk memberi rangsangan dan motivasi yang menantang bagi siswa agar dalam proses pembelajaran siswa merasa terlibat. Guru memberikan kesempatan sebanyakbanyaknya kepada siswa supaya bisa menemukan pengetahuan dan informasi dengan hasil yang didapat dalam pengamatannya. Sehingga siswa bisa dan mampu menemukan hubungan dan prinsip yang tidak diketahui sebelumnya dengan pengalaman belajar yang sudah diatur oleh guru secara seksama (Frikson, 2020).

Hasil dari belajar peserta didik setelah melalui proses belajar daring pada hasil nilai pos test bagi kelompok eksperimen dan kontrol dengan menggunakan kajian non parametrik dan mann whitney bisa di lihat pada tabel 2 berikut dibawah ini.

Table 2. Pembelajaran Daring Berpengaruh pada hasil belajar IPS

\begin{tabular}{lllccc}
\hline No & Variabel & N & Mean & Difference & P-value \\
\hline 1 & $\begin{array}{l}\text { Kelompok } \\
\text { eksperimen }\end{array}$ & 14 & 89.63 & 8.85 & 0.00 \\
\hline 2 & $\begin{array}{l}\text { Kelompok } \\
\text { kontrol }\end{array}$ & 14 & 80.78 & & \\
\hline
\end{tabular}

Hasil dari analisis nilai Mean (nilai rata - rata) untuk klompok eksperimen dengan Mean 89.63 serta untuk klompok kontrol 80.78, difference 8.85. Untuk analsis menggunakan mann whtney $p$-value $0.00<0.05$ sehingga bisa disimpulkan bawa ada pengaruh model pembelajaran daring terhadap hasil dari proses belajar ilmu pengetahuan sosial (IPS).

Hasil dari penelitian yang telah dilakukan bahwa teknik pembelajaran menggunakan metode daring bagi hasil belajar IPS dengan memanfaatkan aplikasi Google Classroom pemahaman materi lebih mudah dipahami oleh siswa dan saat pembelajaran menggunakan metode daring dengan memanfaatkan aplikasi Google Classroom siswa lebih aktif. Apabila dengan memanfaatkan aplikasi Google Classroom dalam proses pembelajaran dengan metode daring terus dilaksanakan maka prestasi yang diraih siswa akan semakin meningkat, dan juga untuk guru bisa menghemat tenaga dan waktu dalam menjalankan tugas mengajar.

Hasil proses belajar menggambarkan keberhasilan yang diraih oleh siswa selepas mengikuti proses belajar-mengajar yang disertai beserta dengan nilainya. Hal ini senada dengan pendapat para ahli dalam teori bahwasanya model pembelajaran daring bisa mengangkat prestasi belajar siswa. Yang mana model pembelajaran daring yang diterapkan dapat memberi pengalaman dalam pembelajaran lebih bermakna bagi siswa.

Diperkuat dari hisil penelitian yang sebelumnya oleh (Khaidi, 2020) dengan judul "Penggunaan 
Media Pembelajran Interaktif Berbasis Web Exe Dalam Meningkaatkan Hasil Belajar Kognitif". Hasil pada penelitian bahwasanya progres keaktifan dan hasil belajar siswa semakin menanjak. Nilai Mean (nilai rata-rata) mencapai 5.9 dengan $35.00 \%$ untuk kerampungan klasikal. Setelah diimplementasikan media pembelajaran berbasis Website, maka hasil yang didapat 7.5 dari hasil belajar siswa dengan 78.28\% ketuntasan klasikal. respon siswa terhadap media belajar yang berbasis Website yaitu $100 \%$ dapat membantu siswa dalam pemahaman terhadap materi juga lebih interaktif dan menyenangkan.

\section{Kesimpulan}

Dari hasil penelitian dapat diambil kesimpulan bahwa model pembelajaran daring dengan memanfaatkan aplikasi Google Classroom khususnya mata pelajaran IPS memberikan dampak yang signifikan terhadap siswa. Data penelitian diolah dan dianalisis menggunakan sofware SPSS menghasilkan nilai Mean (nilai rata - rata) bagi kelompok eksperimen 89.63 dan bagi kelompok kontrol menghasilkan nilai 80.78 Difference 8.85. Dengan analisis menggunakan mann whitney $p$-value $0.00<0.05$ bahwasanya ada damapak dan pengaruh dalam pembelajaran daring bagi hasil pembelajaran IPS, dapat disimpulkan bahwa ada peebedaan yang sangat signifikan antara teknik pembelajaran dengan cara convensional dengan pembelajaran daring dengan memanfaatkan aplikasi Goggle Classroom. Pada hasil penelitian yang didapat bahwa penelitian ini memberikan manfaat serta masukan bagi guru MI Nurul Mun'in untuk mengimplemintasikan model pembelajaran daring untuk meningkatkan hasil prestasi belajar siswa dimana kususnya mata pelajaran Ilmu Pengetahuan Sosial (IPS).

\section{Daftar Pustaka}

Acep , R. H. (2020). Efektifitas Implementasi Pembelajaran Daring (Full Online) Dimasa Pandemi Covid-19 Pada Jenjang Sekolah Dasar Di Kabupaten Subang. Didaktik: Jurnal IImiah PGSD STKIP Subang, VI, 1-9.

Albitar, S. S. (2020). Impelementasi pembelajaran daring untuk meningkatkan mutu pendidikan sebagai dampak diterapkannya social distancing. Jurnal Pendidikan Bahasa dan Sastra Indonesia Metalingua, V, 31-34.

Aniq, A., \& Siti , F. (2020). Penerapan Pembelajaran Daring Dragonlearn pada Era Pandemic Covid-19 (Studi Kasus di MI Ma'had
Islam Kopeng. ISEJ: Indonesian Science Education Journal, I, 148-164.

Eko, K. (2017). Keefektifan model pembelajaran daring dalam perkuliahan bahasa Indonesia di perguruan tinggi. Indonesian Language Education and Literature, 3, 99-110.

Frikson, J. (2020). Analisis Respon Mahasiswa Terhadap Penggunaan Google Classroom Sebagai Media Pembelajaran. JURNAL CURERE, IV, 11-19.

Hikmat, Endang , H., Aldim, \& Irwandi. (2020). Efektivitas pembelajaran daring selama masa pandemi Covid-19. Sebuah survey onlian . LP2M UIN Sunan Gunung Jati, 1-7.

Khaidi. (2020). Penggunaan Media Pembelajaran Interaktif Berbasis Web Exe Dalam Meningkatkan Hasil Belajar Kognitif. Journal: Sudut Pandang, I, 24-30.

$\mathrm{Ni}$, K. S. (2020). Pemanfaatan teknologi informasi dalam pembelajaran tingkat sekolah dasar pada masa pandemi covid-19. Jurnal Lampuhyang Lembaga Penjaminan Mutu Stkip Agama Hindu Amlapura, XI, 13-25.

Novi , R., Fatimatul, E., \& Farid , I. (2020). Analisis Pembelajaran Daring Saat Pandemi Di Madrasah Ibtidaiyah. SITTAH: Journal of Primary Education, I, 139-148.

Ommi , A. (2020). Penerapan Lms-Google Classroom Dalam Pembelajaran Daring Selama Pandemi Covid-19. MAJALAH ILMIAH METHODA, $X, 38-46$.

Roman , A. P., Paulus , I., \& Eko , N. (2019). Faktorfaktor yang mempengaruhi kesuksesan pembelajaran daring dalam revolusi industri 4.0. In Seminar Nasional Teknologi Komputer \& Sains (SAINTEKS), I, 56-60.

Siti , M. (2014). Pendidikan karakter pada matapelajaran ilmu pengetahuan sosial. Jurnal Ilmu Pendidikan, 20, 75-85.

Sobron A.N, Bayu, Rani, \& Meidawati, S. (2019). Pengaruh Daring Learning terhadap Hasil Belajar IPA Siswa Sekolah Dasar. In Seminar Nasional Sains \& Entrepreneurship, $I, 30-38$.

Sobron, A., Titik, S., \& Meidawati, S. (2020, Agustus). STUDI PENGARUH DARING LEARNING TERHADAP HASIL BELAJAR MATEMATIKA KELAS IV. Jurnal Inovasi Penelitian, I(2722-9467), 265-276.

Uwes, A. (2020). Ruang Belajar Baru dan Implikasi terhadap Pembelajaran di Era Tatanan Baru. Jurnal Teknologi Pendidikan, IIX, 142-153. 